\title{
Agrometeorological Requirements of Maize Crop Phenology for Sustainable Cropping-A Historical Review for Romania
}

\author{
Sorin Daniel Vâtcă ${ }^{1}\left(\mathbb{D}\right.$, Valentina Ancuța Stoian ${ }^{1, *(\mathbb{D})}$, Titus Cristian Man ${ }^{2, *(\mathbb{D})}$, Csaba Horvath ${ }^{3} \mathbb{D}^{\mathbb{D}}$, \\ Roxana Vidican ${ }^{4}$, Ștefania Gâdea ${ }^{1}$, Anamaria Vâtcă ${ }^{5}$, Ancuța Rotaru ${ }^{5}$, Rodica Vârban ${ }^{6}$, Moldovan Cristina ${ }^{7}$ \\ and Vlad Stoian ${ }^{4}$
}

check for updates

Citation: Vâtcă, S.D.; Stoian, V.A.; Man, T.C.; Horvath, C.; Vidican, R.; Gâdea, Ș.; Vâtcă, A.; Rotaru, A.;

Vârban, R.; Cristina, M.; et al.

Agrometeorological Requirements of Maize Crop Phenology for Sustainable Cropping-A Historical Review for Romania. Sustainability 2021, 13, 7719. https://doi.org/ $10.3390 /$ su13147719

Academic Editor: Ali Mohammadi

Received: 23 June 2021

Accepted: 8 July 2021

Published: 10 July 2021

Publisher's Note: MDPI stays neutral with regard to jurisdictional claims in published maps and institutional affiliations.

Copyright: (c) 2021 by the authors. Licensee MDPI, Basel, Switzerland. This article is an open access article distributed under the terms and conditions of the Creative Commons Attribution (CC BY) license (https:// creativecommons.org/licenses/by/ $4.0 /)$.
1 Department of Plant Physiology, Faculty of Agriculture, University of Agricultural Sciences and Veterinary Medicine Cluj-Napoca, Calea Mănăştur 3-5, 400372 Cluj-Napoca, Romania; sorin.vatca@usamvcluj.ro (S.D.V.); stefania.gadea@usamvcluj.ro (Ș.G.)

2 Department of Regional Geography and Territorial Planning, Faculty of Geography, Babeș-Bolyai University of Cluj-Napoca, 5-7 Clinicilor Street, 400006 Cluj-Napoca, Romania

3 Department of Physical and Technical Geography, Faculty of Geography, Babeș-Bolyai University of Cluj-Napoca, 5-7 Clinicilor Street, 400006 Cluj-Napoca, Romania; csaba.horvath@ubbcluj.ro

4 Department of Microbiology, Faculty of Agriculture, University of Agricultural Sciences and Veterinary Medicine Cluj-Napoca, Calea Mănăştur 3-5, 400372 Cluj-Napoca, Romania; roxana.vidican@usamvcluj.ro (R.V.); vlad.stoian@usamvcluj.ro (V.S.)

5 Department of Management and Economics, Faculty of Animal Science and Biotechnologies, University of Agricultural Sciences and Veterinary Medicine Cluj-Napoca, Calea Mănăştur 3-5, 400372 Cluj-Napoca, Romania; anamaria.vatca@usamvcluj.ro (A.V.); ancuta.rotaru@usamvcluj.ro (A.R.)

6 Department of Botany, Faculty of Agriculture, University of Agricultural Sciences and Veterinary Medicine Cluj-Napoca, Calea Mănăştur 3-5, 400372 Cluj-Napoca, Romania; rodica.varban@usamvcluj.ro

7 Department of Crop Plant, Faculty of Agriculture, University of Agricultural Sciences and Veterinary Medicine Cluj-Napoca, Calea Mănăştur 3-5, 400372 Cluj-Napoca, Romania; cristina.moldovan@usamvcluj.ro

* Correspondence: valentina.stoian@usamvcluj.ro (V.A.S.); titus.man@ubbcluj.ro (T.C.M.)

\begin{abstract}
Identifying regional variations and agronomical records can turn into a function of magnitude and timing for sustainable maize production. The crop characteristics are directly related with the temperature and precipitation from the growing season. Therefore, the main aim of this study was to highlight maize crop requirements from the most suggestive records from Romania. A literature search was performed based on keywords related to both maize crop and agrometeorological requirements. After the evaluation of the temperature requirements on maize phenology's principal stages, some inconsistencies were identified. These are related to the leaf development stage and the development of the fruit stage, where the minimum temperature interval overlaps with the optimum. A wide variety of assessments were also made, taking into account mainly the monthly temperature and precipitation requirements. The number of principal growth stages assessed differed greatly from one source to another. The growth degree days has been incoherently expressed and calculated, and these details must be taken into account for developing further models. The results regarding phenology aim to propose the setting up of comparable records at a regional (PannEx area) and global scale. This review will help to develop new climate projections in Romania in the climate change context through the project Agroclim.
\end{abstract}

Keywords: temperature; precipitation; heat units; growth; development

\section{Introduction}

Maize (Zea mays L.) originates in the Andean region of Central America. Today, maize is the most globally widespread crop, with a distribution between about $50^{\circ} \mathrm{N}$ and about $45^{\circ} \mathrm{S}$ [1]. Maize is a C4 plant (physiological classification due to the photosynthetic dark pathway) adapted to a hot and dry subtropical climate, with a high annual number of sunshine hours, occasionally heavy rains during the night and limited rains during the day, low wind speed and clay soils [2]. These ecological requirements of maize assure its 
overall sustainable geographical extension and agricultural crop potential, from tropical to temperate suitable climates. The United States produces $32 \%$ of the world's maize, mainly the so-called "corn belt" in the Midwest [3]. At the global scale, it is the most produced crop, being of great importance both for human and animal consumption [4]. The production potential of grains and the composition quality are correlated and strongly influenced by environmental factors such as temperature, total precipitation amount and soil water storage [5]. The average world maize yield is about $5.82 \mathrm{t} \mathrm{ha}^{-1}$, and the crop extends over about 197 million ha worldwide. In Europe, maize is grown on an area of $8,917,080$ ha, with an average production yield of about $7.8 \mathrm{t} \mathrm{ha}^{-1}\left(78,605 \mathrm{hg} \mathrm{ha}^{-1}\right)$ and a total production of $70,092,950$ tons $\mathrm{yr}^{-1}$ [6].

Climate change has become the biggest global challenge, posing threats especially in cropping patterns and yields, leading to food security threats for the growing population $[7,8]$. According to the Fifth Assessment Report of the Intergovernmental Panel on Climate Change, climatic conditions are expected to modify the spatial distribution of crops around the world [9]. Establishing climatic risks for individual crops on a global scale and their future evolution is a key requirement for developing a resilient and robust food production system that ensures food security $[10,11]$. The agricultural ecosystem [12], with social linkages determined by risk perceptions, is influenced by a multitude of external factors, such as market demand, government policies and land ownership. Coupling these connections with the uncertainty impact of climate change on agricultural systems requires a robust methodology with specific indicators which will profile an accurate crop response to climate change [13]. Recent climate models incorporate agriculture as one of the key sectors affected by climate change [14], and they highlight many of the vulnerable components. They require robust indicators and unitary assessments to determine whether the impact is growing and whether food, together with natural resource security, is threatened by risks [13]. Evaluation scales or models cannot be generalized at the global or continental scale, as models were developed for a specific region or country $[5,15,16]$.

Forecast models require large databases, including complex historical observations [17]. Usually, climatic and agronomy research developed in parallel, resulting in multiple observations, but since they have not been collected with a common procedure and aim, the datasets can rarely be completely assembled into a single model. This involves both a reassessment of historical indicators and parameters, and a harmonization procedure in collecting future data. Thus, it will be possible to overlap the phenology of the plant (the biological component) and the climatic dynamics.

In Romania, maize is the most extended crop [18]. As one of the most important cereals both for human and animal consumption, it is especially grown for cereal grains and animal feed [19].

In the European Community, Romania owns 30\% of the total area cultivated with maize. FAOSTAT statistics for 2019 indicated an area of 2,691,930 ha cultivated with maize, an average yield of approximately $6.5 \mathrm{t} \mathrm{ha}^{-1}\left(64,999 \mathrm{hg} \mathrm{ha}^{-1}\right)$ and a total production of 17,432,220 tons $\mathrm{yr}^{-1}$ [6]. These data point out the cropping interest and demonstrate suitability of maize for the eco-pedo-climatic conditions in Romania.

The main objective of this study is to justify the need to reevaluate the existing literature in Romania on maize's requirements regarding the main climatic factors for providing a future sustainability degree.

In response to these requirements and for a better adaptation to a warming climate, the main objective of this paper is to offer a detailed review of the main agronomy and climatic approaches to maize crops in Romania. A literature review was performed based on two different approaches. The first one is related to Romanian literature, especially synthesis books with the term "Maize crop". The search was performed in the online catalogue of University of Agricultural Sciences and Veterinary Medicine Library [http:/ / biblioteca.usamvcluj.ro:8080/liberty/libraryHome.do, (accessed on 9 June 2021)]. From the 311 available titles, only 72 were selected for further analysis. The next step consisted in the selection of the books that clearly state the agrometeorological requirements 
of maize and describe the entire frame of plant growth and development. This selection showed different changes in the climatic assessment of maize due to agronomic advances. The final step was the selection of only those references that contained at least one of the following terms: "temperature", "rainfall regime" and "growing degree days". The second approach is related to the international literature search with the same terms and restrictions. All data were projected on graphs in order to identify both the overlaps between minimum, optimum and maximum requirements, and their integration in the $\mathrm{BBCH}$ scale. Based on this, the maize phenology requirements are more accurate according to agrometeorological indices. The entire process led to a historical framework that highlights how the assessment of maize's climatic requirements evolved during the last 70 years in Romania. The evolution is related to maize breeding programs and the arise of new generations of hybrids both in local and global conditions. This is a prerequisite for establishing a coherent framework in the current context and for the integration with the European Union's common agricultural policy [20]. The study was focused on (i) analyzing the agronomic approach regarding the growth and development evolution of maize plants and the correlation with the international phenological scales; (ii) overlapping historical information on the temperature and precipitation requirements for maize crops; (iii) comparing geographical and agronomic proposals for zoning and based on climatic data; (iv) identifying contradictions between the assessment models for setting the growth degrees days (GDD) amount required for maize.

This study was developed under the framework of the flagship question 1 (FQ1) of the Pannonian Basin Experiment (PannEx) project/network dedicated to the adaptation of agronomic activities to weather and climate extremes [21]. Moreover, this study could become an important tool for agriculture researchers and planners in Romania, but it could also be extended over the PannEx area.

\section{Assessment of Maize Growth and Development-Plant Phenology}

An accurate knowledge of the growth and development process and the biological requirements of a plant at each stage allows the farmer to actively conduct an extensive training process to achieve the crop's productive potential and high yields through the technological means at its disposal [22].

To summarize the growth phases (phenophases) for maize crop, identified by significant qualitative changes in the plant, the maize growing season length has been divided into different stages or phenophases. Each stage extends over a certain period of time, depending on the hybrid, the temperature or day length, the water amount and the available nutrients supply [22]. Thus, for Romania, a different number of stages were identified depending on the author(s) (Table 1).

Initially, the records were made quite briefly and without any specific codification, taking into account 13 important phenophases and with special attention to the organogenesis processes [23]. The following year, a visible improvement, with 10 detailed phases, was based on the detailed assessment of the foliar apparatus formation [24]. Then, three years later, the agriculture decision makers in Romania improved the phenological scale of maize crop growth [22] by individualizing the stages of leaf growth and development. For the more accurate specification of the growth phases, when important qualitative changes in the plant structure can be detected, the maize vegetation period was divided into 10 stages, with the numbering starting from zero. Thus, the first three stages were detailed by using four sub-stages representing the foliar apparatus formation [22]. The establishment of the maize phenology was not unitary among different authors, as there were different moments for observations of the development of their evaluation scales. Depending on the hybrid type approved for cultivation over a specific period and region, the phenological landmarks were: germination, emergence as starting points, the leaves' appearance and sometimes the first internode. Generally most researches focused on phenophases that involved the tassel emergence, spikelets, silking, grain filling or ripening. 
Table 1. Chronological development of phenological scales with a description from Romania.

\begin{tabular}{|c|c|c|c|c|c|}
\hline \multirow{2}{*}{$\begin{array}{l}\text { Source } \\
\text { No.crt. }\end{array}$} & \multirow{2}{*}{$\begin{array}{c}\text { Salontai and Muntean, } 1982 \text { [23]. } \\
\text { Description }\end{array}$} & \multicolumn{2}{|r|}{ Bîlteanu, 1983 [24]. } & \multicolumn{2}{|c|}{ Gruia, 1986 [22]. } \\
\hline & & Phases & Description & Stages & Description \\
\hline 1. & germination-emergence & 0 & germination-emergence & Stage 0 & germination-emergence \\
\hline 2. & $\begin{array}{l}\text { emergence-the formation of the } \\
\text { 3rd leaf }\end{array}$ & $0.5-1$ & 2-4 leaves & Stage 0.5 & $\begin{array}{c}2 \text { leaves (initial leaves } \\
\text { formation) }\end{array}$ \\
\hline 3. & $\begin{array}{l}\text { the formation of the 3rd leaf-the } \\
\text { first internode }\end{array}$ & $1.5-2$ & $6-8$ leaves & Stage 1 & 4 leaves \\
\hline 4. & growth cone formation & $2.5-3$ & 10-12 leaves & Stage 1.5 & 6 leaves \\
\hline 5. & $\begin{array}{l}\text { growth, elongation and } \\
\text { differentiation segments of tassel }\end{array}$ & $3.5-4$ & 14-16 leaves & Stage 2 & 8 leaves \\
\hline 6. & differentiation spikelets in tassel & 5 & $\begin{array}{l}\text { appearance of } \\
\text { stigmas-pollination }\end{array}$ & Stage 2.5 & 10 leaves \\
\hline 7. & differentiation flowers in spikelet & 6 & beginning of grain filling & Stage 3 & 12 leaves \\
\hline 8. & pollen differentiation & 7 & milk grain & Stage 3.5 & 14 leaves \\
\hline 9. & the first internode-formation & 8 & beginning of ripening & Stage 4 & tassel emergence \\
\hline 10. & $\begin{array}{l}\text { tassel formation-stigmata } \\
\text { formation }\end{array}$ & 9 & full ripening & Stage 5 & $\begin{array}{l}\text { silk emergence and the } \\
\text { shaking of pollen }\end{array}$ \\
\hline 11. & stigmata appearance-milk grain & 10 & physiological maturity & Stage 6 & grain filling \\
\hline 12. & milk grain-ripening & & & Stage 7 & milk grain \\
\hline 13. & ripening-full ripening & & & Stage 8 & beginning of ripening \\
\hline 14. & & & & Stage 9 & full ripening \\
\hline 15. & & & & Stage 10 & physiological maturity \\
\hline
\end{tabular}

Even though some maize phenological scales were established at the international level $[25,26]$, the Romanian specialists did not use them, and preferred an agronomic approach based on significant stages observed in the field. The Zadok's growth scale contains 10 principal cereal growth stages. Each primary growth stage is divided into other 10 secondary stages, extending the scale from 00 to 99 . The early growth stages $(1,2$ and 3$)$ are often the most frequently assessed. However, the scale does not run in a chronological order, which could represent a challenge for the beginners in the field. Another approach was created for cereals, especially for planning agro-management strategies like the use of pesticides and fertilizers to avoid damaging the crop and to maximize the crop yield. This system, named Feekes, contains 11 stages. They encompass five growth stages, from which three are divided into five secondary sub-stages and the other two, flowering and ripening, are divided into four sub-stages. To try and obtain a more descriptive scale, $\mathrm{BBCH}$ [27] included some derivation from the Zadok's scale [25] and describes both a general and a-crop specific phenological development, with eight principal growth stages separated in sub-stages for maize. Because of these large diversity scales, the agronomists and seed producers often find it difficult to report results or set recommendations according to a plant's phenological development. A universally accepted scale, easy to use and more appropriate to express a continuous flow in the development steps of a crop is desirable. The references were toward the $\mathrm{BBCH}$ scale, in an attempt to present a new approach for Romania, but also internationally accepted.

The optimum environmental conditions for the plant growth overlap most often with the maximum activity of biotic stressors [28]. This represents a powerful motivation for current and future research in the agroclimatology and ecophysiology fields. A study on benzoxazinoids as plant-derived metabolites highlighted that their accumulation in maize plants is induced by pest and pathogen attacks. These natural bio-stimulated metabolites may have important functions in regulating defense responses, flowering, auxin metabolism, iron absorption and probably tolerance to aluminum [29]. 


\section{Temperature Requirements}

The response of maize to temperature is considered a complex mechanism consisting of metabolic, enzymatic and physiological activity, which allows the plant to adapt and to grow outside the origin areas [28,30].

Starting from this point, field studies and observations have permanently updated the thermal thresholds for different phenophases. Temperature requirements are different depending on the vegetation stage of the plant. Thus, observing the record history of Romania, the minimum germination temperature is $6^{\circ} \mathrm{C}$ [31], or $8{ }^{\circ} \mathrm{C}$ [32]. Some other authors indicated a range of $8-9{ }^{\circ} \mathrm{C}$ [33], respectively $8-10{ }^{\circ} \mathrm{C}$ [34]. From the agronomic point of view, the sowing can start when the soil temperature at a depth of $10 \mathrm{~cm}$ at $8 \mathrm{o}^{\prime}$ clock in the morning is in the range of $8-10{ }^{\circ} \mathrm{C}$, with a continuous daily increasing trend $[31,35,36]$.

A fast and uniform emergence is ensured when the temperature does not fall below $15{ }^{\circ} \mathrm{C}$. After emergence, the temperature requirements increase significantly [31]. The seedlings perish at temperatures between 1 and $4{ }^{\circ} \mathrm{C}$ [37]. At a temperature of $4-5{ }^{\circ} \mathrm{C}$, plant growth stops and even the lightest frosts produce increased damages to the leaves [33]. The appearance of spring frosts also causes great damage to maize hybrids, as the seedlings are severely affected by temperatures below $2{ }^{\circ} \mathrm{C}[32,38]$ and the temperatures of $-4{ }^{\circ} \mathrm{C}$ even for 2 or $3 \mathrm{~h} \mathrm{[24]} \mathrm{completely} \mathrm{compromise} \mathrm{the} \mathrm{crop} \mathrm{by} \mathrm{affecting} \mathrm{all} \mathrm{the} \mathrm{components} \mathrm{of}$ the seedlings [36].

The leaf formation begins at an optimal temperature of $12{ }^{\circ} \mathrm{C}$ [39], but some other authors indicated values equal to or higher than $13^{\circ} \mathrm{C}[23,36,40]$ as more appropriate. The optimal temperature thresholds were identified in the range of $16-20^{\circ} \mathrm{C}$ [34], whereas the maximum growth rate during leaf development is achieved at a temperature equal to or higher than $18{ }^{\circ} \mathrm{C}[23,40]$. The normal growth of maize generally occurs between 20 and $25^{\circ} \mathrm{C}$ [31]. A synthesis of data identified in the Romanian literature is presented in Figure 1. However, the lack of consistency of the temperature data can be noticed and includes minimum intervals for the leaf formation stage of $6-9{ }^{\circ} \mathrm{C}$ [31] and $13-15^{\circ} \mathrm{C}$, interspersing the optimal values between 10 and $13{ }^{\circ} \mathrm{C}$ and 16 and $25^{\circ} \mathrm{C}$, respectively (Figure 1). Assuming maize is a thermophilic plant with a high need for temperature, the minimum growth interval between 13 and $15^{\circ} \mathrm{C}$ and the optimum between 16 and $25^{\circ} \mathrm{C}$, respectively, should be considered as realistic. Currently there are very advanced climate forecasting systems for most of the world's agricultural regions, but for a high-performance model accurate data from a certain cropping region are highly needed.

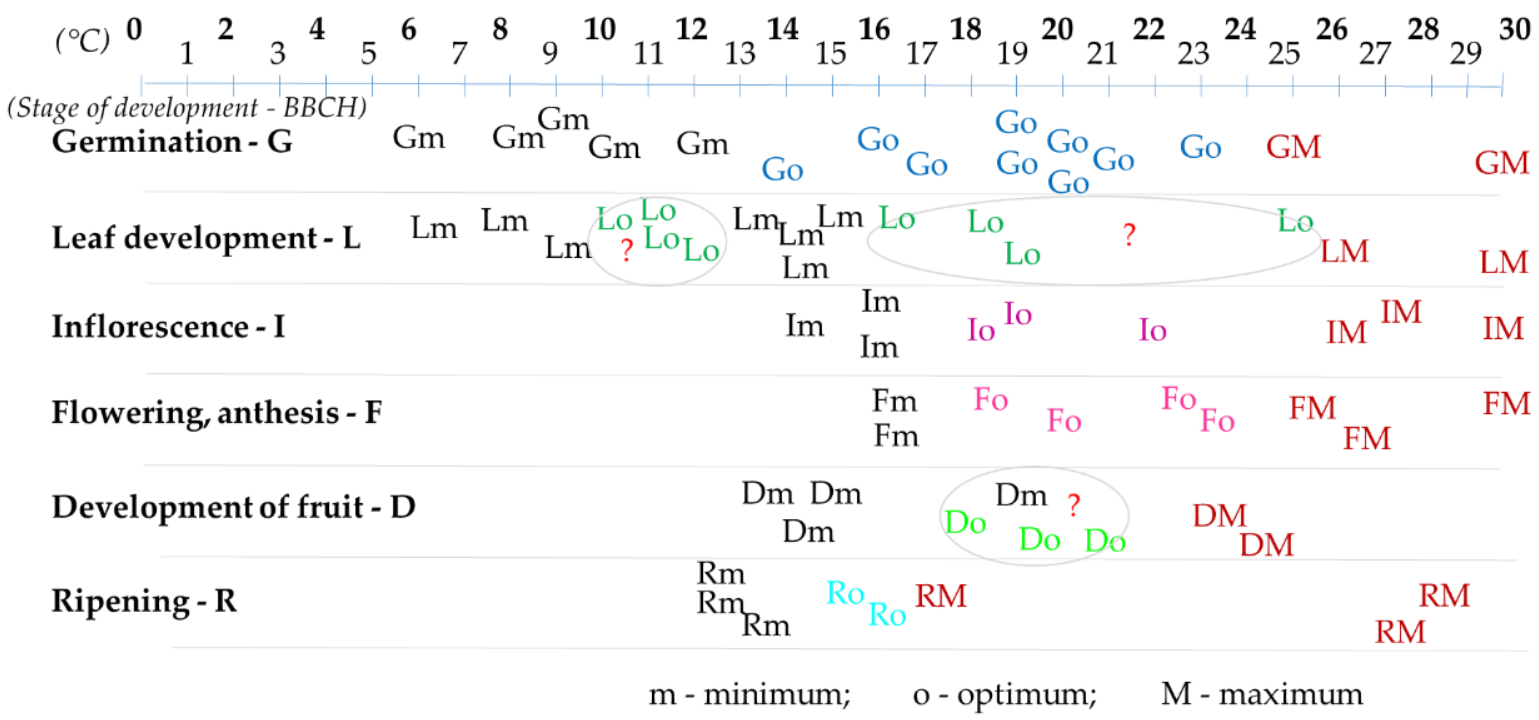

Figure 1. Temperature for maize crop-specific growth and phenophase development. 
Further, in May, the temperature should be higher than $13^{\circ} \mathrm{C}$ for the leaf formation stage, whilst during the tasseling emergence (tassel formation) it should exceed $18{ }^{\circ} \mathrm{C}$. Afterwards, until the silking and during fecundation, a temperature of about $22{ }^{\circ} \mathrm{C}$ is needed for an optimal growth.

During grain formation, the temperature may drop to a minimum value of $19{ }^{\circ} \mathrm{C}$, and during ripening even lower, to $15^{\circ} \mathrm{C}$ [36]. The best results seem to be obtained when the average temperature is around $21^{\circ} \mathrm{C}$, especially during flowering-fecundation. The temperature of the summer months (June-August) must be between 18 and $23^{\circ} \mathrm{C}$ [32]. The heat needed during the fruit development stage is another issue that should be clarified, as there is contradictory information in the literature. Thus, the minimum temperature of $19^{\circ} \mathrm{C}$ should be excluded because it overlaps with the optimum interval. When temperature rises more than $25^{\circ} \mathrm{C}$ [34] or $30^{\circ} \mathrm{C}$ and are accompanied by drought periods during flowering, they are detrimental to the optimal fecundation process, leading to a negative impact on yield [33]. Lower temperatures delay the growing season, and higher temperatures in July and August $\left(22.6-22.8^{\circ} \mathrm{C}\right)$ lead to shriveled grains [31,35] and to a yield decrease, respectively. A small difference of only $2{ }^{\circ} \mathrm{C}$ in July $\left(20.9^{\circ} \mathrm{C}\right)$, along with the cool summer weather, still leads to normal yields. Temperatures below $10^{\circ} \mathrm{C}$ and above $30{ }^{\circ} \mathrm{C}$ stop maize growth [41]. If low temperatures $\left(-1{ }^{\circ} \mathrm{C}\right)$ occur at the end of the vegetation period, they can produce scalding plants [41]. A large daily temperature range (more than $20^{\circ} \mathrm{C}$ ), beginning from the fifth day after fecundation for a period of $2-4$ days, will lead to shriveled grains.

At $30{ }^{\circ} \mathrm{C}$ and low humidity, premature grain ripening occurs, and a temperature of $1.5-3{ }^{\circ} \mathrm{C}$ during milky ripe causes the stopping of organic matter accumulation, grain blackening and destruction. From late milk-ripening stage, maize requires high temperatures and dry climate.

Summarizing the maize heat requirements for Romania, the optimum average temperatures are $16-20{ }^{\circ} \mathrm{C}$ in May, (18)19-21 ${ }^{\circ} \mathrm{C}$ in June, $20-23{ }^{\circ} \mathrm{C}$ in July, $19-20{ }^{\circ} \mathrm{C}$ in August and $14-17^{\circ} \mathrm{C}$ in September [32,34]. Average monthly temperatures should not fall below $13^{\circ} \mathrm{C}$ in May and under $18^{\circ} \mathrm{C}$ in June, July and August. Maize requirements are particularly high also for sunshine hours [31].

In Romania, in the regions suitable for maize cropping, the temperature regime is suitable from the second decade of April until the end of September.

Temperature acts as a severe restrictor for maize if extreme values are reached even for short-term periods [41]. High temperatures affect the speed of physiological processes, which is visible in the length of the growing season and in the speed of maturation. However, higher values will reduce the potential yields [42-44]. The current context of climate changes indicates that future temperatures will have a stronger impact in low latitude areas over the yield potential, and thus will reduce the suitability for maize [45]. The changes will affect the mid- to high-latitude areas to a lesser extent, and in the near and mid-term future a new suitability zoning is needed for growing maize crops, whereas the most affected areas should be converted for other crops [46]. Most of the current models are focused on the assessment of the frequency and severity of extremes, the prediction of heatwaves and the potential presence of drought events during the vegetation periods [21,47]. The results of simulations can be further correlated with a site-specific maize phenology [48] for the establishment of new values for a phenological optimum. All the projections can be further used by seed producers for the selection of hybrids that are more resistant to increased temperatures [49] and the possibility of constantly monitoring the canopy evolution $[50,51]$. Knowledge on the physiological reaction to temperaturerelated stress will establish the potential yield, especially when analyzed in reproductive stages [52]. This will allow the spatio-temporal projection of maize growing conditions within a region and by increasing the resolution it can provide the most suitable plots for this crop [53,54]. There is still a lot of work to be done, especially when the attempt is to analyze the temperatures form a physiological point of view. There are formulas that go from 10 to $30^{\circ} \mathrm{C}$, while others go from 8 to $34{ }^{\circ} \mathrm{C}$, or even from 0 up to $44{ }^{\circ} \mathrm{C}$ [55]. Even 
though the most critical phenological stages were identified, it is quite complicated to provide complete biological information on what will happen with maize based on extreme temperatures, at changes of $1^{\circ} \mathrm{C}$ or less, and how this will affect the biological vegetation period. In the literature, there is information regarding lethal limits for each of the main physiological stages, both for the minimum and maximum temperature [56], but it is still far away from the point when each sub-stage of phenology will be related to the optimum, respectively lethal limits. This data should be obtained both from field observations [57,58], but with a higher accuracy for phenological stages, or from experiments in controlled environments where the observations can be done for each sub-stage [59]. There is still a high uncertainty regarding all the correlations that can be established between phenology and temperature, as well as between each phenological stage related to both temperature and the next stages.

\section{Precipitation Requirements}

Hydrological constraints produce multiple and interconnected effects in the plant [30]. Often, they lead to yield reductions [60]. The most damaging impact is represented by the imbalance of the photosynthetic process [61] mainly generated by the slowing down of growth, the decrease of chlorophyll pigments, the low content of water and stomatal limitations [30]. Under hydrological stress conditions, the plant's transpiration decreases, the membrane permeability consistently diminishes [62] and the active transport slows down, inducing a negative effect on the roots' absorption speed for nutrients and water [63].

Maize grows globally on areas where rainfall is between 250 and $5000 \mathrm{~mm} / \mathrm{yr}$. [34,35]. In its origin region, the amount of rainwater during the vegetation period is $254-330 \mathrm{~mm}$ [32]. For Romania's climatic conditions, it is considered that a minimum amount of precipitation of $250-300 \mathrm{~mm} / 254-330 \mathrm{~mm}$ over the entire vegetation period is needed [32], whereas for the optimal growth process $300-380 \mathrm{~mm}$ are needed [23]. It is classified as a droughtresistant plant, which withstands the drought that occurred during the first vegetation phases more easily, when the requirements for humidity are lower [36]. Maize, due to its long vegetation period, may experience critical phases in case of water shortage that may last quite a long time (from weeks to months), and yet have a high water consumption. Among the reasons for classifying maize as resistant to a lack of soil moisture are the deep root system and adaptation by twisting the leaves to reduce the transpiration [33]. Insufficient humidity in up to six leaves increases the drought resistance of maize in the later development stages. Maize should emerge due only to the soil moisture [35]. For germination, the seed requirements for water are moderate, the grains absorb an amount of about $35 \%$ of their total weight [31]. In Romania's conditions, in the phases from emergence to stem formation, maize can grow in good conditions by using the soil water resources, accumulated during the autumn-winter period. During these phases, the crucial factor for the vegetation process is the heat [35]. In contradiction, there are also data on which the requirements for the water factor are equally high, from emergence to caryopsis development [32]. From the moment of stem elongation and the beginning of tassel emergence, the water factor becomes essential [35]. The importance of precipitation increases in JuneAugust and decreases in September [40]. In July and August [35], when maize passes through the critical stages of anthesis, the grain development and early ripening needs an increased amount of water. During flowering, it is hard for maize to withstand drought. August drought events are harmful, greatly reducing the yield [32]. Especially, the rains during grain development are decisive for maize production [32]. Midday temperatures higher than $25^{\circ} \mathrm{C}$ with maximum values up to $35^{\circ} \mathrm{C}$ in July and August are usually associated with low relative humidity, often due to drought, and hot wind can lead to a strong grain shriveling that can completely compromise the crops [34]. Other studies have found that low rainfall and high temperatures in June and July primarily limit maize production. [38]. A series of studies have concluded that, for maize, it is not the total amount of precipitation plays a decisive role, but the precipitation amount and the distribution during the vegetation period $[23,31,34]$. Although there is quite a lot of information about 
maize's precipitation needs in Romania (Figure 2), the following precipitation amounts are considered optimal: $60-80 \mathrm{~mm}$ in May; $100-120 \mathrm{~mm}$ in June, $100-120 \mathrm{~mm}$ in July and 20(40)-60 mm in August [23,31].

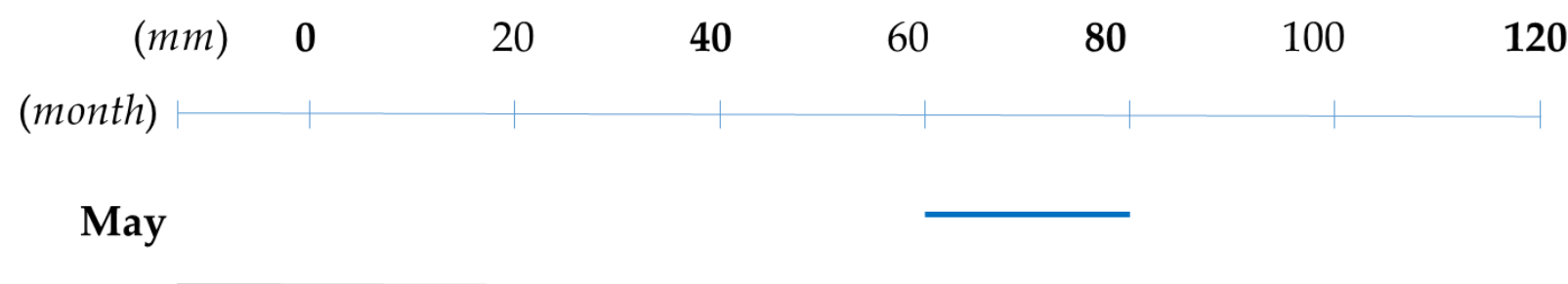

June

July

\section{August}

\section{September}

Figure 2. Monthly precipitation amount requirements for optimal maize crop growth in Romania.

Since September overlaps with the end of the growing season, the amount of rainfall can no longer influence the maize yield. A decrease in maize production was also recorded during a low rainfall over the period between 1-2 weeks before the male inflorescence occurrence and early milk-dough stage development, which usually lasts approximately 5-8 weeks in Romania [36]. During organogenesis, under optimal growing conditions, a maize plant consumes $2-4 \mathrm{~L}$ of water daily during the flowering period until grain formation [31]. Below this value, maize yields diminish considerably [33]. To obtain $3000 \mathrm{~kg} \mathrm{ha}^{-1}$ maize yield, $250-270 \mathrm{~mm}$ of precipitation is required [31]. The daily water requirements in May were established between 15 and $25 \mathrm{~m}^{3} \mathrm{ha}^{-1}$, in June and August between $35-45 \mathrm{~m}^{3} \mathrm{ha}^{-1}$ and the highest in July between $50-60 \mathrm{~m}^{3} \mathrm{ha}^{-1}$ [64]. The lack of water before tassel emergence can reduce the yield by around $30-70 \%$ [64]. A yield reduction between 5 and $45 \%$ can be achieved in the case of poor water supply conditions for four consecutive days in the interval between the tassel emergence and the moment when all kernels have reached final size [41]. Each day of water stress reduces the yield by 2-3 dt ha ${ }^{-1}$. A maize crop does not tolerate water in excess. Standing water on the soil surface either totally compromises or diminishes the yields by up to $10-30 \%$.

Water is the second restrictor for the successful cultivation of a maize crop, whether it is absent or the quantity is too high. The amount required for growth and development is closely related to the temperature, which is also the main driver of the available soil moisture. Water deficits can be related to drought, and even short-term events can cause a high yield reduction [65]. One of the best practices is to deliver supplementary water to plants during the night, which will reduce the temperature around the roots, in addition to the assurance of the required amount for growth and development [66]. When the water is assured, plants respond better to the temperature's upper limits. By contrast, when cells are filled with water and lower (freezing) temperatures occur [67], the plants are more freezing-prone. In case of flooding, the amount of air from the soil decreases, leading to an anoxic zone around the roots [68]. Water-use efficiency is one of the main concerns for the agronomy of this century [69]. The main point of this concept is connected to the assurance of the highest yields possible by adding the needed amounts of water as a supplement 
to rainfall by irrigation. This is necessary especially in semiarid and arid areas [70,71]. This approach requires new and more complex models, which need to consider both the temperature forecast for an area and soil capacity for water retention [72]. A critical need of the new models is the forecasting of rainfall amounts and their frequency during future vegetation periods based on current observed trends [73-75]; the forecast of extreme or punctual events, which can modify the normal vegetation period or even destroy the entire crop $[65,76,77]$. More studies and complex databases are required in order to fulfill the input data for modeling-which will result in the assessment of the phenological adaptation of current genotypes to rainfall, the forecast of survival to precipitation changes and the selection of genotypes that are more resistant to drought [78-82].

\section{Contradictory Concepts on GDD for Maize Crop in the Romanian Literature}

The Growing Degree Days index (GDD) is a universal and the most used current method to assess the temperature requirements of a specific crop during the vegetation period taking into account the atmospheric temperature records. For maize crops, the base temperature encountered is often $10^{\circ} \mathrm{C}[54,83]$. However, in the Romanian literature, numerous terms are used in order to express the same feature: Growth degrees days, Degrees sum, Heat stress degrees sum, Useful temperature sum, Sum degrees, Useful thermal units and Thermic constant.

The thermal resource as a vegetation factor has a very diverse manifestation on the territory both in space and time and determines its division into isothermal area depending on GDD values which create conditions for the survival and development of different plant species. The thermal resource of a certain territory can be achieved by several indicators, derived from the daily temperature records established by the climatological methodology [39].

Although the first classification established considered that to reach full maturity, maize crops need more than $3000^{\circ} \mathrm{C}$ (with $\mathrm{Tb}$ equal to $5^{\circ} \mathrm{C}$ ) active temperatures, when it comes to the different types of hybrids, the value does not exceed $2700{ }^{\circ} \mathrm{C}$ except for the very late hybrids (early hybrids require $2100-2300{ }^{\circ} \mathrm{C}$, semi-early and semi-late hybrids 2400-2500 ${ }^{\circ} \mathrm{C}$, late hybrids $2600-2700{ }^{\circ} \mathrm{C}$ ) [31].

The mismatch in the value assessment of the GDD ("sum of temperatures", as it is called in the Romanian literature) is most likely due to the calculation starting from different biological thresholds. The so-called constant annual amount of temperature values is more variable, as the minimum thresholds that were taken into account are closer to $0{ }^{\circ} \mathrm{C}$. The relationship between the growth rate and the thermal regime is expressed by an effective temperatures sum greater than or equal to $10^{\circ} \mathrm{C}$, with a correlation coefficient of 0.83 . Therefore, for the successive appearance of two leaves, $32.5 \pm 2{ }^{\circ} \mathrm{C}$ effective temperatures higher than $10{ }^{\circ} \mathrm{C}$ are required. At the same time, it was stated that the effective temperature sum of $800-1100{ }^{\circ} \mathrm{C}$ corresponds to the active temperature sums of $2400{ }^{\circ} \mathrm{C}$ and $2900{ }^{\circ} \mathrm{C}$, respectively [40]. The Romanian potential active temperatures are between 3100 and $3800{ }^{\circ} \mathrm{C}$, daytime measurements only. Based on this, if it is taken into account that the double hybrids had a vegetation period between 90 and 1600 days and a thermal constant between 1700 and $3700{ }^{\circ} \mathrm{C}$, it can be concluded that maize finds good vegetation conditions in Romania [34], and that it needs $2000-3000{ }^{\circ} \mathrm{C}$ from emergence to maturity depending on the hybrid [32].

In many maize-growing countries, the heat requirements of maize are assessed by the need for a specific threshold of GDD values for different phases and throughout the entire growing season. Thermal units were calculated differently in Romania using daily air temperatures through various formulas (Table 2). In general, it was considered that the growth of maize standstill below $10{ }^{\circ} \mathrm{C}$ and above $30{ }^{\circ} \mathrm{C}$, and thus the mean daily temperatures below $10{ }^{\circ} \mathrm{C}$, were equivalent to this threshold, and those higher than $30{ }^{\circ} \mathrm{C}$ were considered at a fixed value of $30{ }^{\circ} \mathrm{C}[24]$.

The thermal potential or days with temperatures higher than $10{ }^{\circ} \mathrm{C}$ for maize are high around $3500{ }^{\circ} \mathrm{C}$ [84]. The GDD calculation process consists in the daily summation 
of the maximum and minimum half-temperatures, a half-sum from which the biological threshold of $10^{\circ} \mathrm{C}$ for maize is subtracted (Table 2). In the calculation, temperatures higher than $30^{\circ} \mathrm{C}$ are considered equal to $30^{\circ} \mathrm{C}$, and those lower than $10^{\circ} \mathrm{C}$ are considered equal to $10^{\circ} \mathrm{C}$.

Table 2. Different methods used in Romania to calculate maize's accumulated temperature needs for growth and development.

\begin{tabular}{|c|c|c|c|c|c|}
\hline No. & $\begin{array}{l}\text { Indicator } \\
\text { Name }\end{array}$ & Abbreviation & Formula & Observations & Procedure/Source \\
\hline 1. & $\begin{array}{c}\text { Growth } \\
\text { degrees days }\end{array}$ & GDD & $\sum_{1}^{n}\left(\frac{T^{\circ} \max +T^{\circ} \min }{2}\right)-10^{\circ}$ & $\begin{array}{c}\text { Average daily temperatures }>10^{\circ} \mathrm{C} \\
T>30^{\circ} \mathrm{C}=>T=30^{\circ} \mathrm{C} \\
t<10^{\circ} \mathrm{C}=>t=10^{\circ} \mathrm{C} \\
n \text {-observed growing season length }\end{array}$ & $\begin{array}{c}\text { Classic procedure } \\
\text { [41] }\end{array}$ \\
\hline 2. & Degrees sum & DS & $\begin{array}{c}\sum_{1}^{n}\left(1.18 T \max -0.013 T^{2} \max +\right. \\
0.50 \operatorname{Tmin}-13.3)\end{array}$ & $\begin{array}{c}\text { Daily maximum temperatures } 10-30^{\circ} \mathrm{C} \\
\text { Night temperatures }>5.5^{\circ} \mathrm{C} \\
n \text {-observed growing season length } \\
\text { The most exactly results }\end{array}$ & $\begin{array}{l}\text { Canadian Ontario } \\
\text { procedure } \\
{[41]}\end{array}$ \\
\hline 3. & $\begin{array}{l}\text { Heat stress } \\
\text { degrees sum }\end{array}$ & HS & $\sum_{1}^{n}\left(\frac{T+t}{2}-10^{\circ} \mathrm{C}\right)$ & $\begin{array}{c}T=\text { maximum temperature } \leq 30^{\circ} \mathrm{C}, \\
\text { when } T>30^{\circ} \mathrm{C}=>T= \\
30^{\circ} \mathrm{C}-\left(\operatorname{Tmax}-30^{\circ} \mathrm{C}\right) \\
t=\text { minimum temperature }>10^{\circ} \mathrm{C} . \\
\text { when } t<10^{\circ} \mathrm{C}=>t=10^{\circ} \mathrm{C} \\
n \text { - observed growing season length }\end{array}$ & $\begin{array}{c}\text { Heat stress method } \\
{[41]}\end{array}$ \\
\hline 4. & $\begin{array}{l}\text { Useful } \\
\text { temperature } \\
\text { sum }\end{array}$ & SUT & $\frac{t 1+t 2+t 3+t 4}{4}-10$ & $\begin{array}{c}t 1=\text { air temperature at } 1 \mathrm{o}^{\prime} \text { clock } \\
t 2=\text { air temperature at } 7 \mathrm{o}^{\prime} \text { clock } \\
t 3=\text { air temperature at } 13 \mathrm{o}^{\prime} \text { clock } \\
t 4=\text { air temperature at } 19 \mathrm{o}^{\prime} \text { clock } \\
\sum \text { of daytime temperatures (from } \\
\text { April-October) }\end{array}$ & $\begin{array}{c}\text { Sum of useful } \\
\text { temperatures } \\
\text { [23] }\end{array}$ \\
\hline 5. & Sum degrees & SD & $\sum_{1}^{n} \frac{T^{\circ} \max +T^{\circ} 10}{2}-10$ & $\begin{array}{c}T^{\circ} \max >30^{\circ} \mathrm{C}=>T=30^{\circ} \mathrm{C} \\
T^{\circ} 10<10^{\circ} \mathrm{C}=>T=10^{\circ} \mathrm{C} \\
n \text {-observed growing season length }\end{array}$ & $\begin{array}{l}\text { NOAA method } \\
{[23]}\end{array}$ \\
\hline 6. & $\begin{array}{l}\text { Useful } \\
\text { thermal units }\end{array}$ & UTU & $\sum_{1}^{n} \frac{t 1+t 2+t 3+t 4}{4}-10$ & $\begin{aligned} & t 1=\text { air temperature at } 1 \mathrm{o}^{\prime} \text { clock } \\
& t 2=\text { air temperature at } 7 \mathrm{o}^{\prime} \text { clock } \\
& t 3=\text { air temperature at } 13 \mathrm{o}^{\prime} \text { clock } \\
& t 4=\text { air temperature at } 19 \mathrm{o}^{\prime} \text { clock } \\
& n — \text { observed growing season length }\end{aligned}$ & $\begin{array}{c}\text { Thermic unit need } \\
\text { [24] }\end{array}$ \\
\hline 7. & $\begin{array}{l}\text { Thermic } \\
\text { constant }\end{array}$ & TBA & $\Sigma(\mathrm{Tef}-\mathrm{Tb})$ & $\begin{array}{c}\text { Tef }=\text { effective temperature, expressed as } \\
\text { average daily temperature, averaged } \\
\text { between maximum daily temperature } \\
\text { and minimum daily temperature } \\
\mathrm{Tb}=\text { base temperature or biological } \\
\text { threshold }\left(\mathrm{Tb}<10^{\circ} \mathrm{C}\right)\end{array}$ & $\begin{array}{l}\text { Sum of biologically } \\
\text { active temperatures, } \\
\text { recorded during the } \\
\text { vegetation period } \\
\text { (thermal constant) } \\
\text { [85] }\end{array}$ \\
\hline
\end{tabular}

The Canadian procedure takes into account, for GDD calculation, the maximum daytime temperatures between $10^{\circ} \mathrm{C}$ and $30{ }^{\circ} \mathrm{C}$ and minimum nighttime temperatures above $5.5^{\circ} \mathrm{C}$. The most accurate results are obtained by this process. It allows the correction of the stress caused by too high temperatures. The method of heat stress is considered the maximum temperature when it does not exceed $30^{\circ} \mathrm{C}$ and the minimum if it does not fall below $10^{\circ} \mathrm{C}$ [41]. The GDD on a certain area results from the sum of the average diurnal temperatures from April-October [23]. In order to establish maize hybrids in a certain area, it is necessary to take into account the sum of the active temperature degrees equal to or higher than $10^{\circ} \mathrm{C}$ that can be achieved during their vegetation period [23]. The establishment of suitable areas for maize cropping is based on biological temperature requirements. Throughout the vegetation period, from emergence to physiological maturity, temperatures below 10 are considered as being inactive temperatures for the normal development of the plant's metabolic process. The sum of temperatures higher than $10{ }^{\circ} \mathrm{C}$ over the entire vegetation period of maize is a constant that characterizes hybrids in terms of active heat demand [22]. As a method of determining the sum of the degrees of active temperature starts from the four readings of the average daily air temperature at a height of $2 \mathrm{~m}$ from the ground surface. Subtracting $10{ }^{\circ} \mathrm{C}$ from each reading, their average is the 
sum of the degrees of active temperature for that day, which thus "qualifies" for being introduced in the GDD calculation. The active thermal potential for each area and microzone of the maize crop must be correlated with the thermal requirement of each hybrid type during the vegetation period [22]. TBAs are also called UTU (Useful Thermal Units) or GDD (Growing Degree Days) [84].

For a sum of effective temperatures higher than or equal to $10^{\circ} \mathrm{C}$, the relationship between growth dynamics and thermal regime is very intense, which has led to the recent removal of temperatures below this value from the GDD calculation. Temperatures below the biological survival threshold of maize remain as reference, having a restrictive potential. Thus, it was considered that during the growth season length these temperatures should not occur, because maize is sown only after the weather reaches optimal temperatures with an increase tendency. A recalibration of the models presented in Table 2 is necessary, especially with the integration of extreme thermal events.

\section{Conclusions}

The first conclusion of this study is that the Romanian literature provides a lot of information and interesting approaches, but there is a lack of cohesion between them. Most studies in the last 50 years of the 20th century tried to point out and solve individual climatic problems. In order to understand the basics of maize crops it is necessary to view and compare the data provided by old records dating from around the moment when hybrids were introduced in Romanian agriculture.

The agronomic approach to phenological scales points out germination, leaf formation, tassel formation and ripening as common stages. Consequently, plant phenology in Romania has insisted on generative stages or a vegetative period, together or separately, although the number of principal growth stages assessed differs greatly from one author to another.

In terms of climate requirements, it was found that there is a large diversity of assessments, but most of them consider mainly the temperature and precipitation values on a monthly basis. The most appropriate assessment should be grounded in a phenological basis, considering the crop needs for each phenophase.

In general, the suitability areas of maize crops in Romania considered mainly the topography types (plain, hills, mountains) and only a few climatic indicators, such as monthly temperature and total amount of precipitation. In terms of GDD calculation, a multitude of formulas were presented, but some of them are incomplete.

Under these circumstances, there is a critical need for GDD and other agro-climatic indices to be harmonized and used as global formulas, such as those recommended by the Expert Team for Climate Change Detection and Indices and the Expert Team for SectorSpecific Indices (agriculture) of the World Meteorological Organization-especially those used in ClimPACT (https:/ / climpact-sci.org/, accessed on 14 February 2021) in order to make the results regarding maize vegetation period requirements comparable at a regional (PannEx area) or global scale.

However, considering the similarity of the climatic and soil conditions in the entire Pannonian Basin, it would be extremely useful to extend such a study to the PannEx region in the near future in order to harmonize the terms and approaches based on maize crop phenological features following the $\mathrm{BBCH}$ for the entire region.

Author Contributions: Conceptualization, S.D.V., V.A.S. and V.S.; methodology, T.C.M.; software, V.S., C.H., M.C.; validation, T.C.M., C.H., R.V. and V.S.; formal analysis, V.A.S.; investigation, S.G.; resources, V.A.S.; data curation, V.S., A.V.; writing-original draft preparation, V.A.S., S.D.V., V.S.; writing-review and editing, T.C.M., C.H., R.V. (Rodica Vârban), M.C.; visualization, A.V., A.R., R.V. (Rodica Vârban).; supervision, S.D.V., R.V. (Roxana Vidican), S.G.; project administration, S.D.V., V.A.S. and T.C.M.; funding acquisition, S.D.V. The first author, S.D.V., and the corresponding authors, V.A.S. and T.C.M. have contributed equally to this paper, all three being considered as first authors. All authors have read and agreed to the published version of the manuscript. 
Funding: The publication fee was supported by the Executive Unit for Financing Higher Education, Research, Development, and Innovation (UEFISCDI) in Romania, from the project Redefining agro-climatic suitability zones for maize and winter wheat crops towards smart climate changeoriented agriculture in Romania project number PN-III-P2-2.1-PED-2019-2310), www.agroclim.ro, accessed on 10 January 2021.

Informed Consent Statement: Not applicable.

Data Availability Statement: The data presented in this study are available in the article.

Acknowledgments: This work was supported by grant of the Executive Unit for Financing Higher Education, Research, Development, and Innovation (UEFISCDI) in Romania, for the project $R \boldsymbol{e}$ defining agro-climatic suitability zones for maize and winter wheat crops towards smart climate change-oriented agriculture in Romania project number PN-III-P2-2.1-PED-2019-2310.

Conflicts of Interest: The authors declare no conflict of interest.

\section{References}

1. Leff, B.; Ramankutty, N.; Foley, J.A. Geographic Distribution of Major Crops across the World. Glob. Biogeochem. Cycles 2004, 18. [CrossRef]

2. Andersen, S. Dyrkning Af Korn. In Landbrugsplanterne, 2nd ed.; DSR Forlaget Inc.: Frederiksberg, Denmark, 2000; pp. 106-144.

3. Jiang, Z.; Liu, C.; Ganapathysubramanian, B.; Hayes, D.J.; Sarkar, S. Predicting County-Scale Maize Yields with Publicly Available Data. Sci. Rep. 2020, 10, 1-12. [CrossRef]

4. Giraldo, P.; Benavente, E.; Manzano-Agugliaro, F.; Gimenez, E. Worldwide Research Trends on Wheat and Barley: A Bibliometric Comparative Analysis. Agronomy 2019, 9, 352. [CrossRef]

5. Butts-Wilmsmeyer, C.J.; Seebauer, J.R.; Singleton, L.; Below, F.E. Weather during Key Growth Stages Explains Grain Quality and Yield of Maize. Agronomy 2019, 9, 16. [CrossRef]

6. FAOSTAT. 2019. Available online: http://www.fao.org/faostat/en/\#data/QC (accessed on 15 April 2021).

7. Bennetzen, E.H.; Smith, P.; Porter, J.R. Agricultural Production and Greenhouse Gas Emissions from World Regions-The Major Trends over 40 Years. Glob. Environ. Chang. 2016, 37, 43-55. [CrossRef]

8. Godfray, H.C.J.; Crute, I.R.; Haddad, L.; Lawrence, D.; Muir, J.F.; Nisbett, N.; Pretty, J.; Robinson, S.; Toulmin, C.; Whiteley, R. The Future of the Global Food System; The Royal Society: London, UK, 2010.

9. Kogo, B.K.; Kumar, L.; Koech, R.; Kariyawasam, C.S. Modelling Climate Suitability for Rainfed Maize Cultivation in Kenya Using a Maximum Entropy (MaxENT) Approach. Agronomy 2019, 9, 727. [CrossRef]

10. FAO. The State of Food and Agriculture 2001; Food \& Agriculture Org: Rome, Italy, 2001.

11. Shirley, R.; Pope, E.; Bartlett, M.; Oliver, S.; Quadrianto, N.; Hurley, P.; Duivenvoorden, S.; Rooney, P.; Barrett, A.B.; Kent, C. An Empirical, Bayesian Approach to Modelling the Impact of Weather on Crop Yield: Maize in the US. arXiv 2020, arXiv:2001.02614.

12. Walthall, C.L.; Anderson, C.J.; Baumgard, L.H.; Takle, E.; Wright-Morton, L. Climate Change and Agriculture in the United States: Effects and Adaptation; Iowa State University: Ames, IA, USA, 2013.

13. Hatfield, J.L.; Antle, J.; Garrett, K.A.; Izaurralde, R.C.; Mader, T.; Marshall, E.; Nearing, M.; Robertson, G.P.; Ziska, L. Indicators of Climate Change in Agricultural Systems. Clim. Chang. 2018, 1719-1732. [CrossRef]

14. Melillo, J.M.; Richmond, T.C.; Yohe, G.W. (Eds.) Climate change impacts in the United States: The Third National Climate Assessment. In U.S. Global Change Research Program; Springer Nature: Cham, Switzerland, 2014; pp. 150-174. Available online: http: / / nca2014.globalchange.gov / report (accessed on 23 March 2021). [CrossRef]

15. Peng, B.; Guan, K.; Pan, M.; Li, Y. Benefits of Seasonal Climate Prediction and Satellite Data for Forecasting US Maize Yield. Geophys. Res. Lett. 2018, 45, 9662-9671. [CrossRef]

16. Warren, F.B. Forecasting Corn Ear Weights from Daily Weather Data; New Prairie Press: Manhattan, KS, USA, 1989.

17. Reyer, C.P.; Silveyra Gonzalez, R.; Dolos, K.; Hartig, F.; Hauf, Y.; Noack, M.; Lasch-Born, P.; Rötzer, T.; Pretzsch, H.; Meesenburg, H. The PROFOUND Database for Evaluating Vegetation Models and Simulating Climate Impacts on European Forests. Earth Syst. Sci. Data 2020, 12, 1295-1320. [CrossRef]

18. Popescu, A. Maize and Wheat-Top Agricultural Products Produced, Exported and Imported by Romania. Sci. Pap. Ser. Manag. Econ. Eng. Agric. Rural Dev. 2018, 18, 339-352.

19. Dinca, C.S.; Ion, I.M.D.; Bratoveanu, D.B.; Stanciu, S. Aspects Regarding Maize Crops in the Southeast Region of Romania. Econ. Appl. Inform. 2020, 122-128. [CrossRef]

20. European Union Common Agricultural Policy. Available online: https://ec.europa.eu/info/food-farming-fisheries/key-policies/ common-agricultural-policy_en (accessed on 15 April 2021).

21. Ceglar, A.; Croitoru, A.-E.; Cuxart, J.; Djurdjevic, V.; Güttler, I.; Ivančan-Picek, B.; Jug, D.; Lakatos, M.; Weidinger, T. PannEx: The Pannonian Basin Experiment. Clim. Serv. 2018, 11, 78-85. [CrossRef]

22. Gruia, F. Cultura Porumbului; Centrul de Material Didactic şi Propagandă Agricolă: Bucureşti, Romania, 1986 ; pp. 8-40.

23. Salontai, A.; Muntean, L. Curs de fitotehnie. In Tipo Agronomia; IA Timişoara: Cluj Napoca, Romania, 1982.

24. Bîlteanu, G.; Fazecaş, I.; Salontai, A. Fitotehnie; Editura Didactică şi Pedagogică: Bucureşti, Romania, 1983. 
25. Zadoks, J.C.; Chang, T.T.; Konzak, C.F. A Decimal Code for the Growth Stages of Cereals. Weed Res. 1974, 14, 415-421. [CrossRef]

26. Large, E.C. Growth Stages in Cereals Illustration of the Feekes Scale. Plant Pathol. 1954, 3, 128-129. [CrossRef]

27. Meier, U. Growth Stages of Mono- and Dicotyledonous Plants; BBCH Monograph: Braunschweig, Germany, 2018. [CrossRef]

28. Niemeyer, H.M. Hydroxamic Acids Derived from 2-Hydroxy-2 H-1, 4-Benzoxazin-3 $(4 \mathrm{H})$-One: Key Defense Chemicals of Cereals. J. Agric. Food Chem. 2009, 57, 1677-1696. [CrossRef] [PubMed]

29. Zhou, S.; Richter, A.; Jander, G. Beyond Defense: Multiple Functions of Benzoxazinoids in Maize Metabolism. Plant Cell Physiol. 2018, 59, 1528-1537. [CrossRef] [PubMed]

30. Efeoğlu, B.; Ekmekçi, Y.; Çiçek, N. Physiological Responses of Three Maize Cultivars to Drought Stress and Recovery. S. Afr. J. Bot. 2009, 75, 34-42. [CrossRef]

31. Diaconu, P.; Burloi, G.; Cremenescu, G.; Negrea, I.; Ceaușu, C. Agrofitotehnie; Editura Didactică și Pedagocică: București, Romania, 1978; p. 250.

32. Rogojanu, V.; Chisel, H. Manualul Inginerului Agronom; Ed. Tehnica: Bucuresti, Romania, 1952; Volume I.

33. Taindel, A.; Vrinceanu, V. Fitotehnia; Editura Agro-Silvica: București, Romania, 1962.

34. Dincă, D.; Moscalu, T. Cultura Porumbului; Editura Agro-Silvica: București, Romania, 1967.

35. Ministerul Agriculturii. Cultura Porumbului; Ministerul Agriculturii, Ed.; Agro-Silvică: București, Romania, 1961.

36. Popescu, M.; Popescu, V. Cultura Cerealelor; Ed. Fermierul Roman: București, Romania, 1995.

37. Hera, G.; Sin, G. Metode Agrotehnice în Cultura Plantelor Agricole; Ed Științifică și Enciclopedică: București, Romania, 1980.

38. Coculescu, G.; Ișfan, D. Aplicarea îngrășăMintelor la grîU și Porumb pe Principalelel Tipuri de Sol; Ed. Agro-Silvică: București, Romania, 1967.

39. Teaci, D. Bonitarea Terenurilor Agricole (Farming Land Evaluation); Ed. Ceres: Bucureşti, Romania, 1980.

40. Cristea, M.; Scurtu, D.; Reichbuch, L. Porumbul Timpuriu; Ed. Ceres: Bucuresti, Romania, 1976.

41. Bîlteanu, G.; Bîrnaure, V.; Miclea, E.; Bălașa, M.; Negrilă, A.; Oprea, D.D. Memorator Pentru Producția Vegetală, 2nd ed.; Ed. Ceres: Bucureşti, Romania, 1974.

42. Holzkämper, A.; Calanca, P.; Fuhrer, J. Identifying Climatic Limitations to Grain Maize Yield Potentials Using a Suitability Evaluation Approach. Agric. For. Meteorol. 2013, 168, 149-159. [CrossRef]

43. Mueller, B.; Hauser, M.; Iles, C.; Rimi, R.H.; Zwiers, F.W.; Wan, H. Lengthening of the Growing Season in Wheat and Maize Producing Regions. Weather Clim. Extrem. 2015, 9, 47-56. [CrossRef]

44. Wei, S.; Liu, J.; Li, T.; Wang, X.; Peng, A.; Chen, C. Effect of High-Temperature Events When Heading into the Maturity Period on Summer Maize (Zea mays L.) Yield in the Huang-Huai-Hai Region, China. Atmosphere 2020, 11, 1291. [CrossRef]

45. Gornall, J.; Betts, R.; Burke, E.; Clark, R.; Camp, J.; Willett, K.; Wiltshire, A. Implications of Climate Change for Agricultural Productivity in the Early Twenty-First Century. Philos. Trans. Royal Soc. B: Biol. Sci. 2010, 365, 2973-2989. [CrossRef]

46. Van Bussel, L.G.J.; Stehfest, E.; Siebert, S.; Müller, C.; Ewert, F. Simulation of the Phenological Development of Wheat and Maize at the Global Scale. Glob. Ecol. Biogeogr. 2015, 24, 1018-1029. [CrossRef]

47. Urban, D.; Roberts, M.J.; Schlenker, W.; Lobell, D.B. Projected Temperature Changes Indicate Significant Increase in Interannual Variability of US Maize Yields. Clim. Chang. 2012, 112, 525-533. [CrossRef]

48. Cicchino, M.; Edreira, J.R.; Otegui, M.E. Heat Stress during Late Vegetative Growth of Maize: Effects on Phenology and Assessment of Optimum Temperature. Crop Sci. 2010, 50, 1431-1437. [CrossRef]

49. Tiwari, Y.K.; Yadav, S.K. High Temperature Stress Tolerance in Maize (Zea mays L.): Physiological and Molecular Mechanisms. J. Plant Biol. 2019, 62, 93-102. [CrossRef]

50. Zhang, L.; Niu, Y.; Zhang, H.; Han, W.; Li, G.; Tang, J.; Peng, X. Maize Canopy Temperature Extracted from UAV Thermal and RGB Imagery and Its Application in Water Stress Monitoring. Front. Plant Sci. 2019, 10, 1270. [CrossRef]

51. Bassu, S.; Fumagalli, D.; Toreti, A.; Ceglar, A.; Giunta, F.; Motzo, R.; Niemeyer, S. Potential Maize Yields in a Mediterranean Environment Depend on Conditions around Flowering. In Proceedings of the ICROPM2020: Second International Crop Modelling Symposium, Montpellier, France, 3-5 February 2020.

52. Naveed, S.; Aslam, M.; Maqbool, M.A.; Bano, S.; Zaman, Q.U.; Ahmad, R.M. Physiology of High Temperature Stress Tolerance at Reproductive Stages in Maize. J. Anim. Plant Sci. 2014, 24, 1141-1145.

53. Hou, P.; Liu, Y.; Xie, R.; Ming, B.; Ma, D.; Li, S.; Mei, X. Temporal and Spatial Variation in Accumulated Temperature Requirements of Maize. Field Crops Res. 2014, 158, 55-64. [CrossRef]

54. Croitoru, A.-E.; Man, T.C.; Vâtcă, S.D.; Kobulniczky, B.; Stoian, V. Refining the Spatial Scale for Maize Crop Agro-Climatological Suitability Conditions in an Area with Complex Topography towards a Smart and Sustainable Agriculture. Case Study: Central Romania (Cluj County). Sustainability 2020, 12, 2783. [CrossRef]

55. Kumudini, S.; Andrade, F.H.; Boote, K.J.; Brown, G.A.; Dzotsi, K.A.; Edmeades, G.O.; Gocken, T.; Goodwin, M.; Halter, A.L.; Hammer, G.L. Predicting Maize Phenology: Intercomparison of Functions for Developmental Response to Temperature. Agron. J. 2014, 106, 2087-2097. [CrossRef]

56. Sánchez, B.; Rasmussen, A.; Porter, J.R. Temperatures and the Growth and Development of Maize and Rice: A Review. Glob. Chang. Biol. 2014, 20, 408-417. [CrossRef]

57. Templ, B.; Koch, E.; Bolmgren, K.; Ungersböck, M.; Paul, A.; Scheifinger, H.; Busto, M.; Chmielewski, F.-M.; Hájková, L.; Hodzić, S. Pan European Phenological Database (PEP725): A Single Point of Access for European Data. Int. J. Biometeorol. 2018, 62, 1109-1113. [CrossRef] 
58. Rosemartin, A.; Denny, E.G.; Gerst, K.L.; Marsh, R.L.; Posthumus, E.E.; Crimmins, T.M.; Weltzin, J.F. USA National Phenology Network Observational Data Documentation. US Geol. Surv. Open-File Rep. 2018, 24, 1018-1060.

59. Shim, D.; Lee, K.-J.; Lee, B.-W. Response of Phenology-and Yield-Related Traits of Maize to Elevated Temperature in a Temperate Region. Crop J. 2017, 5, 305-316. [CrossRef]

60. Rockström, J.; Karlberg, L.; Wani, S.P.; Barron, J.; Hatibu, N.; Oweis, T.; Bruggeman, A.; Farahani, J.; Qiang, Z. Managing Water in Rainfed Agriculture-the Need for a Paradigm Shift. Agric. Water Manag. 2010, 97, 543-550. [CrossRef]

61. Meyers, T.P.; Hollinger, S.E. An Assessment of Storage Terms in the Surface Energy Balance of Maize and Soybean. Agric. For. Meteorol. 2004, 125, 105-115. [CrossRef]

62. Kaya, C.; Tuna, L.; Higgs, D. Effect of Silicon on Plant Growth and Mineral Nutrition of Maize Grown under Water-Stress Conditions. J. Plant Nutr. 2006, 29, 1469-1480. [CrossRef]

63. Hu, Y.; Burucs, Z.; von Tucher, S.; Schmidhalter, U. Short-Term Effects of Drought and Salinity on Mineral Nutrient Distribution along Growing Leaves of Maize Seedlings. Environ. Exp. Bot. 2007, 60, 268-275. [CrossRef]

64. Redactia De Propaganda Tehnica Agricola. Indrumări Tehnice Pentru Lucrătorii din Agricultură-Producția Vegetală; Ministerul Agriculturii și Alimentației-Direcția Tehnică și Învățământ, Centrul de Material Didactic și propaganda Agricolă-Redacția de Propagandă Tehnică Agricolă: București, Romania, 1990.

65. Hatfield, J.L.; Dold, C. Climate Change Impacts on Corn Phenology and Productivity. Corn Prod. Hum. Health Chang. Clim. 2018, 95. [CrossRef]

66. Berti, A.; Maucieri, C.; Bonamano, A.; Borin, M. Short-Term Climate Change Effects on Maize Phenological Phases in Northeast Italy. Ital. J. Agron. 2019, 14, 222-229. [CrossRef]

67. Streck, N.A.; Silva, S.D.; da Langner, J.A. Assessing the Response of Maize Phenology under Elevated Temperature Scenarios. Rev. Bras. Meteorol. 2012, 27, 1-12. [CrossRef]

68. Sachs, M.M.; Subbaiah, C.C.; Saab, I.N. Anaerobic Gene Expression and Flooding Tolerance in Maize. J. Exp. Bot. 1996, 47, 1-15. [CrossRef]

69. Kang, S.; Shi, W.; Zhang, J. An Improved Water-Use Efficiency for Maize Grown under Regulated Deficit Irrigation. Field Crops Res. 2000, 67, 207-214. [CrossRef]

70. Veron, S.R.; Paruelo, J.M.; Oesterheld, M. Assessing Desertification. J. Arid Environ. 2006, 66, 751-763. [CrossRef]

71. Le Houérou, H.N. Climate Change, Drought and Desertification. J. Arid Environ. 1996, 34, 133-185. [CrossRef]

72. Ao, S.; Russelle, M.P.; Feyereisen, G.W.; Varga, T.; Coulter, J.A. Maize Hybrid Response to Sustained Moderate Drought Stress Reveals Clues for Improved Management. Agronomy 2020, 10, 1374. [CrossRef]

73. Liu, Y.; Qin, Y.; Ge, Q. Spatiotemporal Differentiation of Changes in Maize Phenology in China from 1981 to 2010. J. Geogr. Sci. 2019, 29, 351-362. [CrossRef]

74. Guo, E.; Zhang, J.; Wang, Y.; Alu, S.; Wang, R.; Li, D.; Ha, S. Assessing Non-Linear Variation of Temperature and Precipitation for Different Growth Periods of Maize and Their Impacts on Phenology in the Midwest of Jilin Province, China. Theor. Appl. Clim. 2018, 132, 685-699. [CrossRef]

75. Neild, R.E. Temperature and Rainfall Influences on the Phenology and Yield of Grain Sorghum and Maize: A Comparison. Agric. Meteorol. 1982, 27, 79-88. [CrossRef]

76. Vina, A.; Gitelson, A.A.; Rundquist, D.C.; Keydan, G.; Leavitt, B.; Schepers, J. Monitoring Maize (Zea mays L.) Phenology with Remote Sensing. Agron. J. 2004, 96, 1139-1147. [CrossRef]

77. Oteros, J.; García-Mozo, H.; Botey, R.; Mestre, A.; Galán, C. Variations in Cereal Crop Phenology in Spain over the Last Twenty-Six Years (1986-2012). Clim. Chang. 2015, 130, 545-558. [CrossRef]

78. Zia, S.; Romano, G.; Spreer, W.; Sanchez, C.; Cairns, J.; Araus, J.L.; Müller, J. Infrared Thermal Imaging as a Rapid Tool for Identifying Water-Stress Tolerant Maize Genotypes of Different Phenology. J. Agron. Crop Sci. 2013, 199, 75-84. [CrossRef]

79. Tonnang, H.E.; Makumbi, D.; Craufurd, P. Methodological Approach for Predicting and Mapping the Phenological Adaptation of Tropical Maize (Zea mays L.) Using Multi-Environment Trials. Plant Methods 2018, 14, 1-12. [CrossRef] [PubMed]

80. Zhang, Z.; Yang, X.; Liu, Z.; Bai, F.; Sun, S.; Nie, J.; Gao, J.; Ming, B.; Xie, R.; Li, S. Spatio-Temporal Characteristics of Agro-Climatic Indices and Extreme Weather Events during the Growing Season for Summer Maize (Zea mays L.) in Huanghuaihai Region, China. Int. J. Biometeorol. 2020, 64, 827-839. [CrossRef]

81. Yang, Y.; Anderson, M.C.; Gao, F.; Johnson, D.M.; Yang, Y.; Sun, L.; Dulaney, W.; Hain, C.R.; Otkin, J.A.; Prueger, J. Phenological Corrections to a Field-Scale, ET-Based Crop Stress Indicator: An Application to Yield Forecasting across the US Corn Belt. Remote Sens. Environ. 2021, 257, 112337. [CrossRef]

82. Sah, R.P.; Chakraborty, M.; Prasad, K.; Pandit, M.; Tudu, V.K.; Chakravarty, M.K.; Narayan, S.C.; Rana, M.; Moharana, D. Impact of Water Deficit Stress in Maize: Phenology and Yield Components. Sci. Rep. 2020, 10, 1-15.

83. Pandžić, M.; Ljubičić, N.; Mimić, G.; Pandžić, J.; Pejak, B.; Crnojević, V. A Case Study of Monitoring Maize Dynamics in Serbia by Utilizing SENTINEL-1 Data and Growing Degree Days. ISPRS Ann. Photogramm. Remote Sens. Spat. Inf. Sci. 2020, 3, 117-124. [CrossRef]

84. Bîlteanu, G.; Fazekaș, I.; Salontai, A.; Bîrnaure, V.; Ciobanu, F.; Vasilică, C. Fitotehnie; Ed. Didactică și Pedagogică: Bucureşti, Romania, 1979.

85. Ion, V. Fitotehnie; Editura USAMV: Bucureşti, Romania, 2010. 